\title{
Effect of Historical Zinc Processing on Soil: A Case Study in Southern Poland
}

\author{
Katarzyna Sutkowska ${ }^{1}$, Leslaw Teper ${ }^{1}$, Aleš Vaněk ${ }^{2}$, Tomasz Czech ${ }^{3}$, Agnieszka Baran $^{3}$ \\ ${ }^{1}$ Department of Applied Geology, Faculty of Earth Sciences, University of Silesia \\ Bedzinska 60, 41-200 Sosnowiec, Poland \\ katarzyna.sutkowska@us.edu.pl; leslaw.teper@us.edu.pl \\ ${ }^{2}$ Department of Soil Science and Soil Protection, Faculty of Agrobiology, Food and Natural Resources \\ Czech University of Life Sciences Prague \\ Kamycka 129, Prague 6, Czech Republic \\ vaneka@af.czu.cz \\ ${ }^{3}$ Department of Agricultural and Environmental Chemistry, University of Agriculture in Krakow \\ al. A. Mickiewicza 21, 31-120 Kraków, Poland \\ tomasz.czech@ur.krakow.pl; abaran2@ar.krakow.pl
}

\begin{abstract}
The present study focuses on the geochemical hazard in the soil system affected by the historical zinc processing in Jaworzno, Southern Poland. We measured pH, total sulphur and total carbon values as well as total $\mathrm{Zn}, \mathrm{Pb}$ and $\mathrm{Cd}$ content (ICP-OES) for soil samples and waste material. Essential information about the heavy metal bioavailability and toxic impact on the natural environment was delivered by the modified three-steps sequential extraction method (BCR). The application of soil enzyme activity analysis and the bioassay test with Vibrio fischeri allow us to assess the effect of heavy metal toxicity/bioavailability on active soil environment. We conclude that after 40 years since $\mathrm{Zn}$ processing was abandoned, the total content of $\mathrm{Zn}, \mathrm{Pb}$ and $\mathrm{Cd}$ in the investigated soil is extremely high, ca.8 to 28 times larger than in the European topsoils and about twofold above the values of geochemical background for the Southern Poland. In view of above statements and results of bio-tests, we note that the area of current study is strongly affected by the historical zinc industry and the topsoil is heavily contaminated or even toxic.
\end{abstract}

Keywords: $\mathrm{Zn}$ smelting, $\mathrm{ZnO}$ processing, heavy metals, waste, soil toxicity

\section{Introduction}

Our study focuses on the geochemical hazard in the soil system affected by the historical zinc processing in Jaworzno, Southern Poland. We measured physical properties ( $\mathrm{pH}$, total sulphur and total carbon values) as well as total heavy metals $(\mathrm{Zn}, \mathrm{Pb}$ and $\mathrm{Cd})$ content (ICP-OES) for soil samples and leftover material. Essential information about the heavy metal bioavailability and toxic impact on the natural environment was delivered by the modified three-steps sequential extraction method (BCR). The application of soil enzyme activity analysis (dehydrogenase analysis - DHA) and the bioassay test with Vibrio fischeri allow us to assess the effect of heavy metal toxicity/bioavailability on active soil environment.

\section{Material and methods}

The research was conducted in an industrial and anthropogenically altered city space of Jaworzno, located in the NE part of the Upper Silesia, Southern Poland. The $\mathrm{Zn}-\mathrm{Pb}$ ore mining and smelting started here in 12th and lasted to 20th century. In the area of the study, the $\mathrm{Zn}$ smelter was established in 1822 . Then it was transformed to white zinc ( $\mathrm{ZnO})$ plant in the 1865, which was finally closed in the 1976. Non-sulfide $\mathrm{Zn}$ ore from local mines served as the raw material for $\mathrm{Zn}$ smelting. Nowadays, the relics of the Zn historical metallurgic processes are represented by tailings deposited on the old heap situated in close vicinity of residential area and community gardens.

The study was conducted on 4 forest soil profiles of the podzol and 5 waste samples collected from 3 waste locations. Each soil profile was divided into separate horizons, what gave 22 soil samples. Soil $\mathrm{pH}$ was obtained using pHmeter ELMETRON CP-315m. Concentration of total carbon (TC), total sulphur (TS) and total inorganic carbon (TIC) were 
determined by an Eltra CS-530 IR-analyzer with a TIC module. The chemical fractionation forms of the studied metals were obtained using the modified BCR sequential extraction given by Rauret et al.[1]. Exchangeable, reducible, oxidizable and residual fractions were separated and the heavy metals contents in each fraction were determined using ICP-OES. Microbial activity in the analyzed soil, was conducted based on the Casida et al. [2] method with the use for reduction 2, 3, 5- triphenyltetrazolium chloride (TTC) to the creaming red-colored formazan (TPF). The red methanolic solutions of the formazan were read at $485 \mathrm{~nm}$ with the use of Spectrophotometer UV-Vis, DU 640. The toxicity assessment of soil and waste was performed with Microtox M500 Analyzer. In the test, decrease in luminescence in Vibrio fischeri was measured, which is an effect of metabolic inhibition in the bacteria after exposure to a toxic substance.

\section{Results and discussion}

Values of soil $\mathrm{pH}$ fluctuate between 3.85 and 7.59 , with median 5.55. The waste samples show mostly very low-pH characteristic (values vary from 2.83 to 7.41 ). It means that examined materials are ultra-acidic to neutral, mostly very strong acidic. Generally, $\mathrm{pH}$ value decreases with depth. TOC values obtained for the soil range from $0,1 \%$ to $22.07 \%$, with a mean $1,57 \%$, while amount of TS vary from 0 to $0,17 \%$. Both parameters mostly decrease with depth. In waste samples TOC value fluctuate between $0,42 \%$ and $8,86 \%$ whereas TS change in the range from $0,09 \%$ to $0,78 \%$. Higher content of the sulphur in the waste may be connected with sulfides naturally occurred in $\mathrm{Zn}-\mathrm{Pb}$ ores used in smelting process.

Investigated soil samples contain 9.53 - $2307.52 \mathrm{mg}$. kg-1 d.m. of $\mathrm{Zn}, 3.07-531.09 \mathrm{mg}$. kg-1 d.m. of Pb and $0.16-$ $17.62 \mathrm{mg}$. kg-1 d.m. of Cd, with geometrical means $91.76 \mathrm{mg}$. kg-1 d.m., $38.45 \mathrm{mg}$. kg-1 d.m. and $1.31 \mathrm{mg}$. kg-1 d.m., respectively. Load of the same elements in the waste ranges as follows: $25.89-4625.82 \mathrm{mg} . \mathrm{kg}-1 \mathrm{~d} . \mathrm{m}$. (Zn), $60.21-$ $3932.94 \mathrm{mg}$. kg-1 d.m. $(\mathrm{Pb})$ and $0.11-14.64 \mathrm{mg}$. kg-1 d.m. (Cd), with geometrical means $173.56 \mathrm{mg}$. kg-1 d.m., 269.41 $\mathrm{mg}$. kg-1 d.m. and $0.93 \mathrm{mg}$. kg-1 d.m., correspondingly. The total contents of $\mathrm{Zn}, \mathrm{Pb}$ and $\mathrm{Cd}$ in the soil are definitely above the values of geochemical background for the Southern Poland [3]. The levels of metal concentrations in the topsoil are over 2- and even 3-fold higher than the baseline concentrations. In the comparison with European soils [4], the studied soil is severely contaminated. The $\mathrm{Zn}, \mathrm{Pb}$ and $\mathrm{Cd}$ contents exceed median value 8 -fold, 11 -fold and 28 -fold, respectively. However, compared to the $\mathrm{Zn}-\mathrm{Pb}$ ore long-lasting mining and smelting sites in Poland [5-8] and all over the world [9-11], the heavy metal contents in the studied topsoil are at least 2-times lower.

The sequential extraction procedure (SEP) delivers information on the mobility of heavy metals in soil profiles [12]. $\mathrm{Zn}$ in the topsoil is related to the exchangeable (49.8\%), reducible $(20.2 \%)$ and organic/oxidizable (18.4\%) phases. The residual (11.7\%) fraction is of minor importance. The $\mathrm{Zn}$ fractionation in the whole soil profiles $\mathrm{Zn}$ looks slightly different, with depletion of exchangeable (42.2\%) and reducible (15.9\%) phases as well as with enrichment of residual (21.7\%) and organic (20.1\%) fractions. The largest amount of $\mathrm{Pb}$ is associated with the reducible fraction, accounting for about $44.5 \%$ for topsoil and $43.5 \%$ for whole profiles. The next most substantial phase is the organic/oxidizable with $37.4 \%$ and $29.7 \%$, respectively. Residual and exchangeable phases reached lower lead accumulation ca. 10\% and $14.3 \%$ also $8.1 \%$ and $12.5 \%$, correspondingly. The cadmium is mainly extracted in the exchangeable fraction (53\% and 55.6\%, accordingly from the topsoil and whole profile) and in the reducible fraction (31.1\% and $22.9 \%)$. The organic/oxidizable and residual fractions, getting about $10 \%$, are of the minor importance.

Our results suggest that the mobility and bioavailability of $\mathrm{Zn}, \mathrm{Pb}$ and $\mathrm{Cd}$ in the topsoil decline in the order $\mathrm{Cd}>\mathrm{Zn}>$ $\mathrm{Pb}$. It is also seen, that generally, the participation of the residual fraction increased with depth. These findings are in line with those of Ullrich et al. [6], Li \& Thornton [13] and Gruszecka \& Wdowin [14]. Moreover, when compared with Chrastný et al. [8], they follow Ettler's [15] announcement that the proportion of contaminants in the "labile" fractions of sequential extraction procedures, and subsequent vertical mobility, is generally higher for forest than for agricultural soils.

The results of toxicity assessment of study soil and waste samples by bacteria $\mathrm{V}$. fischeri are presented below. In the soil samples the luminescence inhibition of $\mathrm{V}$. fischeri is between: 51 to $84 \%$ for profile $1,-10$ to $54 \%$ for profile 2,52 to $89 \%$ for profile 3 and between 17 to $77 \%$ for profile 4 . Depending on the studied waste samples, V. fischeri luminescence inhibition was from 66 to 95\% (sample I), 43\% (sample II) and 46\% (sample III). The toxicity classification developed by Persoone et al. [16] was used to estimate soil and waste sample toxicity. According to the classification, soils collected from sampling sites 1 and 3 are toxic (class III). Toxicity of soil sampled from profile 4 vary from class III (deeper parts) by II to I (topsoil). Soil collected from profile 2 shows the lowest toxicity to the test organisms. Most samples in this profile are intoxic (class I), but upper horizons are still classified into toxicity class III. Waste samples were classed as III (toxic, sample I) and II (low toxic, samples I and II). 


\section{Conclusion}

After 150 years since $\mathrm{Zn}$ smelter was closed and 40 years since $\mathrm{ZnO}$ plant was abandoned, the total content of $\mathrm{Zn}, \mathrm{Pb}$ and $\mathrm{Cd}$ in the investigated soil is extremely high, ca.8 to 28 times larger than in the European topsoils [4] and about twofold above the values of geochemical background for the Southern Poland [3].

The total heavy metal concentration (from ICP-OES) in topsoil does not describe bioavailability well. The BCR procedure brings more useful details. According to BCR results, over the half of total $\mathrm{Zn}, \mathrm{Pb}$ and $\mathrm{Cd}$ content can be easily transferred from topsoil downward and to the other parts of environment.

In view of above comments and results of bio-tests, we note that the area of current study is strongly affected by the historical zinc industry and the topsoil is heavily contaminated or even toxic.

\section{Acknowledgements}

This study was performed in the framework of the statutory activities of the University of Silesia, Katowice and was funded by the University of Silesia, Faculty of Earth Sciences (grant number 1M-0413-001-1-01). Project was also supported by the Centre for Polar Studies, University of Silesia Poland - The Leading National Research Centre (KNOW) in Earth Sciences 2014-2018. We wish to thank Dr Maria Racka from the University of Silesia in Katowice for her assistance with TOC and TS analysis.

\section{References}

[1] G. Rauret, J. F. Lopez-Sanchez, A. Sahuquillo, E. Barahona, M. Lachica, A. M. Ure, C. M. Davidson, A. Gomez, D. Luck, J. Bacon, M. Yli-Halla, H. Muntau and P. Quevauviller, "Application of a modified BCR sequential extraction (three-step) procedure for the determination of extractable trace metal contents in a sewage sludge amended soil reference material (CRM 483), complemented by a three-year stability study of acetic acid and EDTA extractable metal content," J. Environ. Monit., vol. 2, pp. 228-233, 2000.

[2] L. E. Casida Jr., D. A. Klein and T. Santoro, "Soil dehydrogenase activity," Soil Sci., vol. 98, pp. 371-376, 1964.

[3] A. Pasieczna, "Wpływ przemysłu na środowisko przyrodnicze regionu śląsko-krakowskiego," Gospod. Surowcami Min., vol. 24, no. 2/2, pp. 67-82. 2008.

[4] R. Salaminen, Ed., Geochemical Atlas of Europe Part 1 and 2. Geological Survey of Finland, 2005.

[5] J. F. Verner, M. H. Ramsey, E. Helios-Rybicka and B. Jedrzejczyk, "Heavy metal contamination of soils around a $\mathrm{Pb}-\mathrm{Zn}$ smelter in Bukowno, Poland," Appl. Geochem., vol. 11, pp. 11-16, 1996.

[6] S. Ullrich, M. Ramsey and E. Helios-Rybicka, "Total and exchangeable concentrations of heavy metals in soils near Bytom, an area of $\mathrm{Pb} / \mathrm{Zn}$ mining and smelting in Upper Silesia, Poland," Appl. Geochem., vol. 14, pp. 187-196, 1999.

[7] J. Cabala and K. Sutkowska, "Past exploitation and processing of $\mathrm{Zn}-\mathrm{Pb}$ ore influence on the industrial soil minerals composition, Olkusz and Jaworzno district," Prace Nauk. Inst. Górnictwa Polit. Wroct. Studia i Materiaty, vol. 117, pp. 13-22, 2006.

[8] V. Chrastný, A. Vaněk, L. Teper, J. Cabala, J. Prochazka, L. Pechar, P. Drahota, V. Penizek, M. Komarek and M. Novak, "Geochemical position of $\mathrm{Pb}, \mathrm{Zn}$ and $\mathrm{Cd}$ in soils near the Olkusz mine/smelter, South Poland: effects of land use, type of contamination and distance from pollution source," Environ. Monit. Assess., vol. 184, pp. 2517-2536, 2012.

[9] Y. G. Yang, C. Q. Liu, W. Pan, G. P. Zhang and W. H. Zhu, "Heavy metal accumulation from zinc smelters in a carbonate rock region in Hezhang country, Guizhou province, China," Water Air Soil Poll., vol. 174, pp. 321-339, 2006.

[10] L. Rodríguez, E. Ruiz, J. Alonso-Azcárate and J. Rincón, "Heavy metal distribution and chemical speciation in tailings and soils around a Pb-Zn mine in Spain," J. Environ. Manage., vol. 90, no. 2, pp. 1106-1116, 2009.

[11] H. Y. Zhan, Y. F. Jiang, J. Yuan, X. F. Hu, O. D. Nartey and B. L Wang, "Trace metal pollution in soil and wild plants from lead-zinc smelting areas in Huixian County, Northwest China," J. Geochem. Explor., vol. 147, pp. 182188, 2014.

[12] A. Vaněk, V. Chrastný, M. Komárek, V. Penížek, L. Teper, J. Cabala and O. Drábek, "Geochemical position of thallium in soils from a smelter-impacted area," J. Geochem. Explor., vol. 124, pp. 176-182, 2013. 
[13] X. D. Li and I. Thornton, "Chemical partitioning of trace and major elements in soils contaminated by mining and smelting activities," Appl. Geochem., vol. 16, pp. 1693-1706, 2001.

[14] A. M. Gruszecka and M. Wdowin, "Characteristics and distribution of analyzed metals in soil profiles in the vicinity of a postflotation waste site in the Bukowno region, Poland," Environ. Monit. Assess, vol. 185, pp. 8157-8168, 2013.

[15] V. Ettler, "Soil contamination near non-ferrous metal smelters: A review," Appl. Geochem., vol. 64, pp. 56-74, 2016.

[16] G. Persoone, B. Marsalek, I. Blinova, A. Torokne, D. Zarina, L. Manusadzianas, G. Nalecz-Jawecki, L. Tofan, N. Stepanova, L. Tothova and B. Kolar, "A practical and user-friendly toxicity classification system with microbiotests for natural waters and wastewaters," Environ. Toxicol., vol. 18, pp. 395-402, 2003. 